\title{
The relevance of glacier melt in the water cycle of the Alps: the example of Austria
}

\author{
G. R. Koboltschnig ${ }^{1}$ and W. Schöner ${ }^{2}$ \\ ${ }^{1}$ International Research Society INTERPRAEVENT, \% Dept. of Water Management, Provincial Government of Carinthia, \\ Klagenfurt, Austria \\ ${ }^{2}$ Climate Research Dept., Central Institute of Meteorology and Geodynamics (ZAMG), Vienna, Austria
}

Received: 2 April 2010 - Published in Hydrol. Earth Syst. Sci. Discuss.: 10 May 2010

Revised: 24 May 2011 - Accepted: 7 June 2011 - Published: 29 June 2011

\begin{abstract}
This paper quantifies the contribution of glacier melt to river runoff from compilation and statistical interpretation of data from available studies based on observations or glacio- hydrological modelling for the region of Austria (Austrian Salzach and Inn river basin). A logarithmic fit between the glacier melt contribution and the relative glacierized area was found not only for the long-term mean glacier contributions but also for the glacier melt contribution during the extreme hot an dry summer of 2003. Interestingly, the mean contributions of glacier melt to river runoff do not exceed $15 \%$ for both river catchments and are uncorrelated to glacierization for glacierization values $>10 \%$. This finding, however, has to be seen in the light of the general precipitation increase with altitude for the study region which levels out the increase of absolute melt with glacierization thus resulting in the rather constant value of glacier melt contribution. In order to qualitatively proof this finding another approach has been applied by calculating the quotient $q_{\mathrm{A} 03}$ of the mean monthly August runoff in 2003 and the long-term mean August runoff for 38 gauging stations in Austria. The extreme summer 2003 was worth to be analysed as from the meteorological and glaciological point of view an extraordinary situation was observed. During June and July nearly the entire snow-cover melted and during August mainly bare ice melt of glaciers contributed to runoff. The $q_{\mathrm{A} 03}$ quotients were calculated between 0.32 for a non-glacierized and 2.0 for a highly glacierized catchment. Using the results of this study the mean and maximum possible glacier melt contribution of catchments can be estimated based on the relative glacierized area. It can also be shown that the found correlation of glacierized area and glacier melt contribution is applicable for the Drau basin where yet no results of modelled glacier melt contributions are available.
\end{abstract}

Correspondence to: G. R. Koboltschnig (gernot.koboltschnig@ktn.gv.at)

\section{Introduction}

For mountain hydrology the contribution of snow- and glacier melt to river runoff is of outmost interest. Especially in the context of future climate change scenarios water managers would like to know what could happen if glaciers strongly retreat or even disappear and what the consequences for water management could be. Is there a possibility for floods due to increasing glacier melt? Will decreasing glacier melt caused by a reduced glacierized area affect and lower low flow during dry spells in summer? Several studies, in particular for the European Alps, were performed to answer these questions. Generally, discharge contribution from glaciers is well described by the glacier mass balance, which - from a storage approach - balances the water balance loss for precipitation due to snow accumulation with gain from ice and firn melt. Thus mass balance trends can be interpreted as trends in the discharge contribution from glaciers. However, using a pure "melt contribution" approach only the ablation term is taken into account whereas accumulation is disregarded. Consequently, two different approaches have been used in literature to define the role of glaciers for river discharge. One uses bare ice (including firn) melt (e.g. Koboltschnig et al., 2008) and the other one derives glacier contribution from glacier storage change (e.g. glaciers only contribute to runoff when annual mass balances are negative, see e.g. Lambrecht and Mayer, 2009). Whereas the first approach separates ice- and firn melt from snow melt contribution.

Alpine glaciers are known to react sensitive to climate change (see e.g. Oerlemans et al., 1998) by adjusting their size and altitudinal position to changes in mass balance and flow dynamics. Consequently, outstanding negative mass balances and large melt contributions to river flow occur in climatological extreme years with respect to the mean climate as e.g. the year 2003 for the European Alps. Koboltschnig et al. (2008) found out for a small, $5 \%$

Published by Copernicus Publications on behalf of the European Geosciences Union. 
glacierized catchment in a year with slightly negative glacier mass balance that the annual glacier melt contribution (bare ice and firn melt) was $1 \%$ and in the year 2003 with extremely negative glacier mass balances it was $15 \%$ of the total runoff. Comparing the glacier melt contribution during the month of August for these two climatologically different years $4 \%$ for the balanced year and $58 \%$ for 2003 were calculated.

In the European Alps the summer of 2003 was reported as the hottest and driest summer ever observed since the beginning of meteorological observations (Beniston, 2004; Schär and Jendritzky, 2004). Even at high-elevation meteorological stations new extremes of highly positive temperatures were broken. During August 2003 the mean air temperature at Sonnblick observatory was about $4{ }^{\circ} \mathrm{C}$ higher than the long term mean from 1886 to 2000 (Koboltschnig et al., 2009). The effects of this outstanding summer on glaciers causing extreme ablation and an extraordinary reduction of snow covered areas and firn areas were reported in Paul et al. (2005) and Koboltschnig et al. (2009). Zappa and Kan (2007) evaluated the extreme heat and its effects on the runoff extremes in the Swiss Alps by using historical discharge records. They calculated that the 2003 summer runoff from Swiss Alpine basins was only $60-80 \%$ (from the Swiss Central Plateau even less) of the long-term average runoff. For glacierized catchments the opposite was shown. Koboltschnig et al. (2008) showed for the Austrian Upper Salzach catchment that especially in June but also in July 2003 the melt water contribution still mainly originated from snow melt. Concerning hydrological impacts of the extreme summer 2003 Eybl et al. (2005) reported that the hydropower production at river Danube in Austria was reduced during August 2003 by one third. But in highly glacierized and summer- snowmelt dominated catchments an even higher hydropower production was possible compared to average conditions. Furthermore Koboltschnig et al. (2008) calculated from a LANDSAT image, taken on 24 August 2003 that snow covered only $11 \%$ of the glaciers surface in the Austrian Upper Salzach basin. At mountain stations snow disappeared very early in the summer of 2003 (see Fig. 2). The high-elevation station of Sonnblick observatory (3106 m a.s.l., see Fig. 2. and Fig. 3) got snow-free in August 2003. Using satellite-based observations of the glacier surface albedo Paul et al. (2005) found that snow cover on glaciers was the lowest in August 2003 compared to other summer observations. Parajka and Bloeschl (2006) showed a composite MODIS image from June 2003 with nearly no snow cover over Austria. Glacier mass balance observations in the Alps reported an extreme retreat of snow cover in the summer of 2003 (WGMS, 2005).

Hence, there is a good possibility to investigate the bare ice glacier melt contribution from the example of the summer 2003 as there were nearly snow free conditions. Though, the meteorological situation of the summer 2003 was exceptional, its temperature data series can act as a useful example for scenario simulations for the end of the 21 st century.
Some first results on the role of glaciers in the water cycle of Austria can be derived from glacier inventories. For Austria detailed inventories (including size, volume change, topography) are available for 1969 and approx. 1998 (Lambrecht and Kuhn, 2007). Total area in 1998 was $470 \mathrm{~km}^{2}$ ( $0.56 \%$ of the area of Austria) and total volume was estimated (from measurements and simple scaling) as $17.4 \mathrm{~km}^{3}$. For the water cycle of Austria this is equivalent to a water storage of $185 \mathrm{~mm}$ which is about $15 \%$ of the annual precipitation in Austria. Volume loss of glaciers between 1969 and 1998 were estimated as $-4.9 \mathrm{~km}^{3}$ for Austria (Lambrecht and Kuhn, 2007), which is $52 \mathrm{~mm}$ (1.8 mm per year) of water with respect to the Austrian water cycle. This is only $0.16 \%$ of the annual precipitation. These results, however, have to be interpreted in the context of spatially and temporally uneven distributed melt contributions of glaciers.

In this paper we first summarize studies on glacier melt contribution to river runoff for the Alps and in particular for the region of Austria. Then we use modelled and measured data from available studies for Austria to statistically analyse the relationship between glacierized area and runoff contribution from glacier melt. As these data are available only for the Inn and Salzach catchments we introduce another statistical relationship between long-term mean discharge and August 2003 discharge (with exceptional large contribution of glaciers to river runoff) in order to test the robustness of the findings and to spatially transfer it to a third large river catchment.

\section{Review of different studies on glacier melt contribution in the Alps and their results}

Kuhn (2004) investigated the reaction of the mean monthly runoff of glacierized and non-glacierized catchments using the semi-distributed runoff model OEC and a simple air temperature and precipitation scenarios approach. In another study Kuhn et al. (2007) simulated the monthly glacier melt contribution (from May to September) for glacierized catchments in western Austria for the reference period 19832003. The catchment area with the highest glacierization is the Gepatsch catchment with about $40 \%$ glacierized area. Within the reference period the relative glacier melt contribution had a calculated maximum of $20 \%$ in the month of August. Furthermore it was $0 \%$ in May, $10 \%$ in June, $15 \%$ in July and $14 \%$ in September. Compared to that the ice melt contribution of the $1.5 \%$ glacierized catchment area of Radurschl had its maximum in August with $2 \%$. Furthermore Kuhn et al. (2009) calculated the mean annual ice melt contribution for the period from 1982 to 2003 for the 15,32 and $39 \%$ glacierized catchments Tumpen ( $8 \%$ contribution), Obergurgl (9\% contribution) and Vent-Rofenache (7\% contribution). The authors additionally applied climate change scenarios to study the impact on glacier melt contribution 


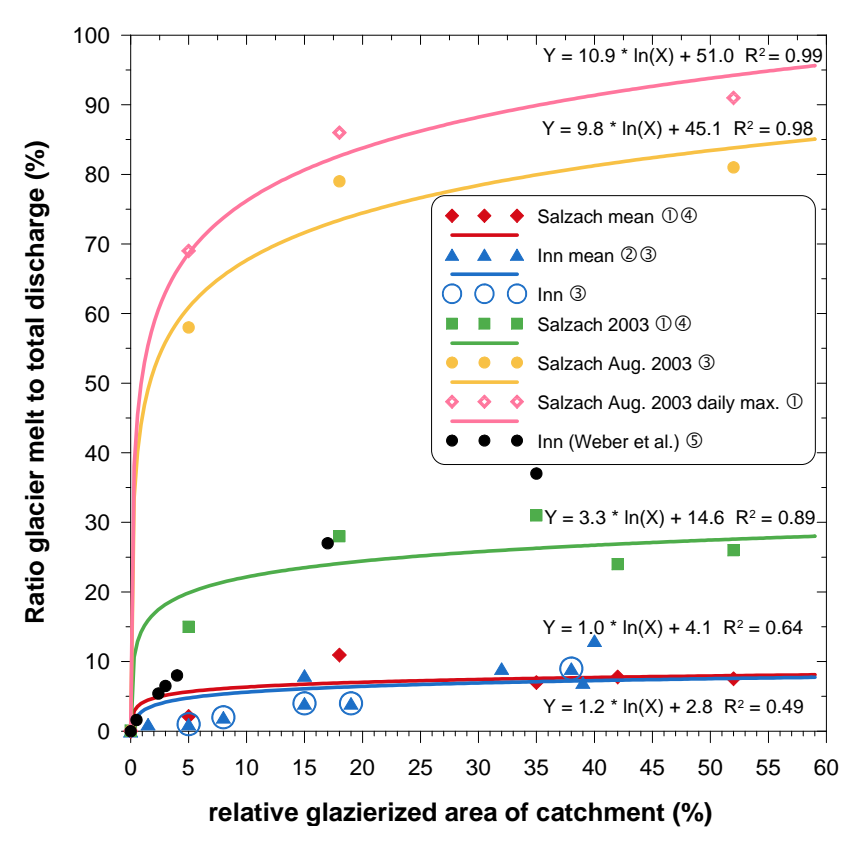

Fig. 1. Maximum daily, August 2003, 2003 annual and long-term mean relative glacier melt contribution vs. relative glacierization of the Inn and Salzach basin. Displayed data were compiled from different published studies. Encircled numbers in the legend indicate study references in Table 1.

under a future climate. As the glacier scenarios did not account for changes of glacier surfaces some other uncertainty had to be included for future changes.

Schaefli et al. (2005) applied a semi-lumped conceptual glacio- hydrological model for the joint simulation of daily discharge and annual glacier mass balance to Swiss catchments. The model was calibrated using daily discharge and annual glacier mass balance data. The model of Schaefli et al. (2005) already incorporates glacier surface evolution with time. Running this model with climate change scenarios from climate models Schaefli et al. (2007) simulated the potential future discharge evolution for a catchment with a hydropower station in Switzerland. A decrease of $36 \%$ of the annual hydropower production was calculated for the scenario period (2070-2099) - mainly because of the decrease in precipitation and ice melt and the increase in evapotranspiration. At the same time the simulated glacier surface reduced by $40 \%$. As the actual and future hydropower production depends on several components (availability of water, electricity demand and offer, hydropower management strategies, ... ) and their uncertainties, which have been taken into account in the considerations of Schaefli et al. (2007), there is no linear relation between the decrease of runoff (water availability) and the decrease of hydropower production.

Huss et al. (2008) simulated the possible future runoff until 2100 for the three Swiss glacierized catchments of Glacier de Zinal $\left(11.4 \mathrm{~km}^{2}\right.$ glacierized area, $65 \%$ glacierization),
Glacier de Moming $\left(6.0 \mathrm{~km}^{2}\right.$ glacierized area, $63 \%$ glacierization), and Glacier du Weisshorn $\left(2.7 \mathrm{~km}^{2}\right.$ glacierized area, $39 \%$ glacierization) driving a glacio- hydrological model with regional climate model data. The model took the glacier surface changes into account by adjusting the glaciers extent and surface elevation. It was calibrated and validated using DEMs (digital elevation models) of the past glacier surface and additionally against monthly runoff observations. For the near future, until approx. 2040, an increase of the glacier melt contribution was simulated because sufficient glacial storage is available. Later runoff decreases for all applied scenarios and drops below the current situation between 2060 and 2080, which is due to the decrease of glacial storage. Although Huss et al. (2008) did not explicitly calculate the contribution of glacier melt they simulated a substantial change of the mean monthly runoff regime from glacial to nival shifting the runoff maximum from July/August to May/June. Studying long-term hydrographs Collins (2008) found out that glacierized catchments in the upper Rhone basin already reached the maximum runoff between 1940 and 1950. Runoff from glacierized basins increased gradually from the Little Ice Age maximum in the late 19th century before rising rapidly in the 1940s. After decreasing with falling temperatures to the late 1970s, rising runoff levels during the second warming period (since the begin of the 1980s) failed to exceed those attained during the first. Melt rates continued to increase, but it was insufficient to offset the shrinking glacier surfaces.

Huss et al. (2009) found another reason for the obviously higher glacier melt in the 1940s. They concluded that in the 1940s Alpine glacier melt could have been stronger due to enhanced solar radiation. Therefore it could be possible that the currently lower runoff volumes noted by Collins (2008) in comparison to the 1940 s and 1950s could be explained with the importance of radiation.

Weber et al. (2009 and 2010) reported on the application of the model DANUBIA, which was used to simulate the past and future glacier contribution for the river Danube and glacierized tributaries from the south (Inn and Salzach). They found out that the $35 \%$ glacierized catchment of Vent/Rofenache had a mean annual contribution of glacier melt of $36.9 \%$, the $17 \%$ glacierized catchment Huben/Ötztalerache had a mean annual contribution of glacier melt of $26.5 \%$ and the $4 \%$ glacierized catchment Inn/Innsbruck had a mean annual contribution of glacier melt of $8.4 \%$ for the period 1991-2000. Future simulations were based on REMO and MM5 climate generators. Results showed a shift of the runoff regime for the higher glacierized catchments from glacial to nival but nearly no influence of the glacier retreat was shown for the largest catchment Achleiten/Donau $\left(76600 \mathrm{~km}^{2}\right.$, actually $0.5 \%$ glacierized) as the actual glacier melt contribution is already quite low $(1.6 \%)$.

For two western Austrian basins Lambrecht and Mayer (2009) calculated the excess discharge, which additionally 

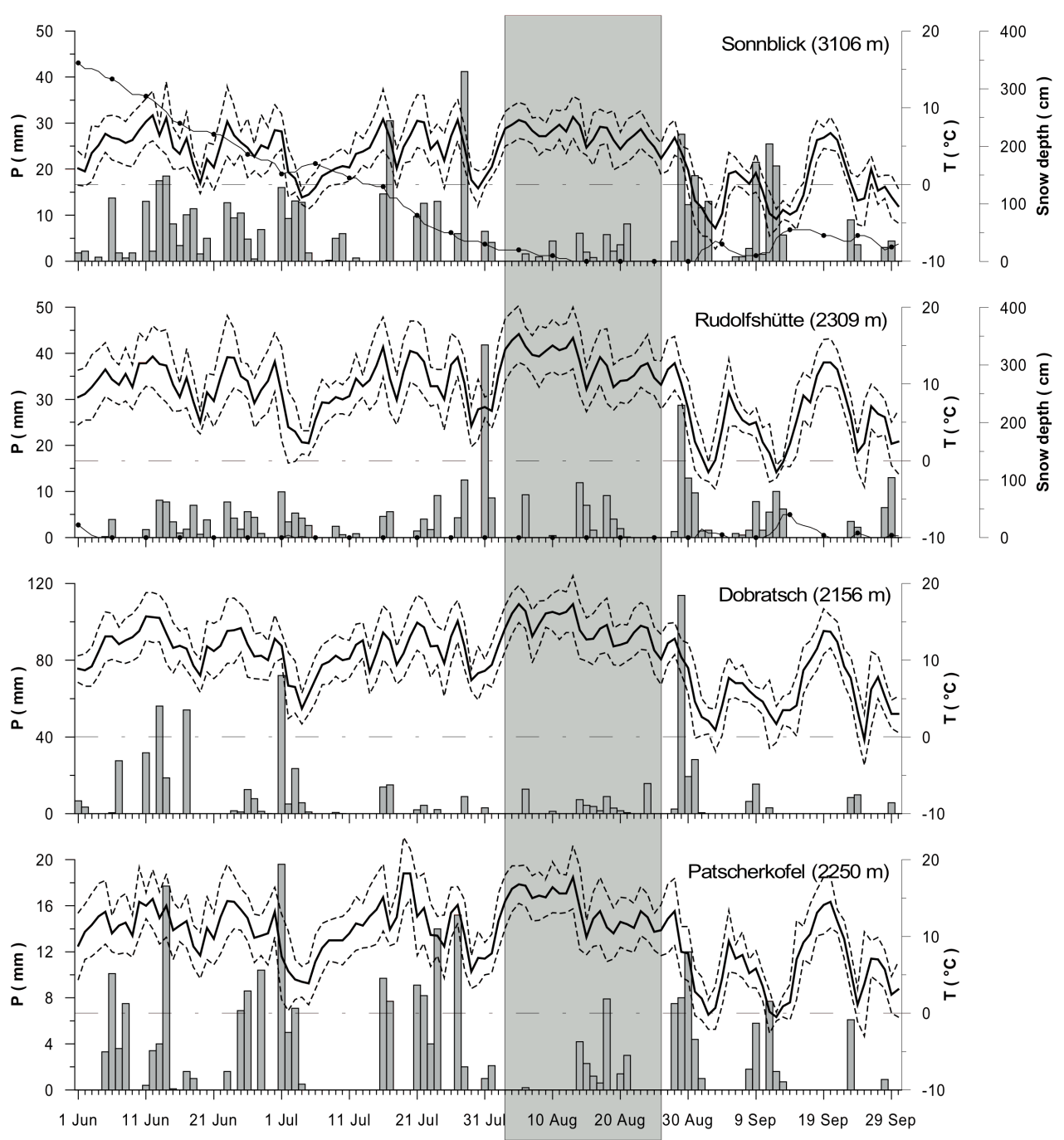

Fig. 2. Meteorological observations from four elevated stations in Austria (the location can be seen in Fig. 3) from 1 June to 30 September 2003. The dark black line is the daily mean air temperature and the grey dashed lines are the corresponding daily minimum and maximum air temperatures. Grey bars are the daily precipitation amounts and the black dotted lines at the two uppermost diagrams are the observed snow depths. The grey zone indicates the investigated time span from 3 to 27 August 2003.

contributes to runoff during periods of glacier retreat. The calculation is based on two glacier inventories in 1969 and in 1998, on annual glacier mass balance data and a degree-day approach. They computed the additional amount of runoff, which originates from glaciers. For the entire period from 1969 to 1998 the excess was between 1.5 and $9 \%$ depending on the degree of glacierization $(4-40 \%)$. The fraction increased for summer months to $3-12 \%$. In a highly glacier covered catchment the excess reached a maximum value of $40 \%$. The excess discharge is not directly comparable to other results of studies investigating glacier melt contribution as during years of positive or even zero mass balance no excess discharge is calculated. Melt during steady state conditions cannot be considered.
All mentioned studies have shown different approaches to calculate the glacier melt contribution on different spatial scales. Nevertheless, observed glacier mass balances were necessary for all of these studies either to calculate the glacier melt contribution directly combined with a simple melt model or to use them for the calibration of complex hydro-meteorological models.

\section{Methods}

The basic idea of our study was to investigate and quantify the contribution of glacier melt to total river runoff for different catchment areas and varying glacierization. Therefore we compiled measured and modelled data of glacier melt 
Table 1. Data source of available glacier melt contribution values for the Inn (Danube) and Salzach basin including the calculation method, the definition of glacier melt and calculation period.

\begin{tabular}{|c|c|c|c|c|c|c|}
\hline Nr. & reference & basin & method & $\begin{array}{l}\text { definition of } \\
\text { glacier melt }\end{array}$ & period & available data \\
\hline 1 & $\begin{array}{l}\text { Koboltschnig (2007a) } \\
\text { Koboltschnig et al. } \\
\text { (2008 and 2009) }\end{array}$ & Salzach & $\begin{array}{l}\text { hydrological model } \\
\text { PREVAH }\end{array}$ & $\begin{array}{l}\text { ice (and firn) } \\
\text { melt }\end{array}$ & $2000-2005$ & $\begin{array}{l}\text { mean of period } \\
\text { mean } 2003 \\
\text { mean } 08 / 2003 \\
\text { daily max } 2003\end{array}$ \\
\hline 2 & $\begin{array}{l}\text { Kuhn, et al. (2007 } \\
\text { and 2009) }\end{array}$ & Inn & $\begin{array}{l}\text { hydrological model } \\
\text { OEZ }\end{array}$ & $\begin{array}{l}\text { ice (and firn) } \\
\text { melt }\end{array}$ & $1983-2003$ & mean of period \\
\hline 3 & Lambrecht and Mayer (2009) & Inn & $\begin{array}{l}\text { mass balance/ } \\
\text { degree day model }\end{array}$ & storage change & 1969-1998 & mean of period \\
\hline 4 & $\begin{array}{l}\text { Slupetzky and } \\
\text { Wiesenegger (2005) }\end{array}$ & Salzach & $\begin{array}{l}\text { estimate from } \\
\text { measurements }\end{array}$ & storage change & 1964-2003 & $\begin{array}{l}\text { mean } 2003 \\
\text { mean of period }\end{array}$ \\
\hline 5 & Weber et al. (2009) & Inn & $\begin{array}{l}\text { hydrological model } \\
\text { DANUBIA/Surges }\end{array}$ & $\begin{array}{l}\text { ice (and firn) } \\
\text { melt }\end{array}$ & $1991-2000$ & mean of period \\
\hline
\end{tabular}

contributions from different studies in the Austrian Alps. As not for all glacierized basins and all gauging stations calculated glacier melt contributions were available another method for checking the spatial transferability of the results was needed. Therefore we used the example of the extreme hot and dry summer of 2003 when glacier melt at least partly compensated for the runoff loss.

\subsection{Compilation of a glacier melt contribution dataset out of different studies}

Table 1 shows a compilation of different studies in which the glacier melt contributions of the Austrian Inn and Salzach basin were calculated. For each catchment the ratio of glacier melt to total discharge (glacier contribution) and the corresponding relative glacierized area were calculated. The results of Koboltschnig (2007a) and Koboltschnig et al. (2008 and 2009) were taken as the mean of the period 2000 to 2005 excluding the extreme year of 2003. Monthly results of Kuhn et al. (2007), which were available as mean values for the period from 1983 to 2003 for the months from May to September, were taken for the calculation of annual mean values by assuming that the glacier melt contribution within the other months was zero. All other glacier contributions (Weber et al., 2009; Kuhn et al., 2009 and Lambrecht and Mayer, 2009) were available as annual mean values of long-term periods. In Fig. 1 glacier melt contributions were plotted for the Inn and the Salzach basin. Although belonging to the Inn basin results of Weber et al. (2009 and 2010) were displayed separately. Their results were too different from the other studies - further details on that are mentioned later in the results and discussion section. Additionally the mean glacier contribution of the year 2003 and August 2003 as well as the daily maximum contribution of the year 2003 were displayed. For all these plots a logarithmic curve was fitted and the fitting function displayed.

\subsection{Assessment of the glacier melt contribution based on observed discharge data of the extreme summer 2003}

In order to assess the effects of the hot and dry summer of the year 2003 for different glacierized catchments in Austria the runoff quotient $q_{\mathrm{A} 03}$ (see Eq. 1) was calculated. Therefore 28 gauging stations from the three main glacierized basins in the Austrian Alps Inn, Salzach and Drau (see Fig. 3), three stations at river Danube, two stations at river Traun (both with a low degree of glacierization) and five additional stations of rivers with non-glacierized catchments were selected (see Table 2) to compare the mean August runoff in the year 2003 to the long-term August mean, similar to the study of Zappa and Kan (2007). Considering the hot and dry meteorological situation, rivers without glacierization should have a quotient of far below 1 and rivers with high glacierization a quotient of above 1. Differently from our study Zappa and Kan (2007) decided to compare the summer 2003 discharge (from 1 June to 30 September) with the long-term mean summer discharge by taking the longest available discharge record for each station. Their goal was to show the runoff extremes (below and above the average). Within this study we tried to evaluate the statistical relation between glacier melt contribution and the catchments glacierization. The calculation of the quotient $q_{\mathrm{A} 03}$ was worth to be analyzed, as in 2003 glacier mass balances were the most negative ever observed (WGMS, 2005 and Koboltschnig et al., 2008). The relation between the quotient $q_{\mathrm{A} 03}$ and the catchments glacierization cannot directly be used to asses the melt contribution of glacierized catchments but it is a proof for the relation of calculated or modelled melt contributions (see above mentioned results of studies) and the catchments glacierization. 


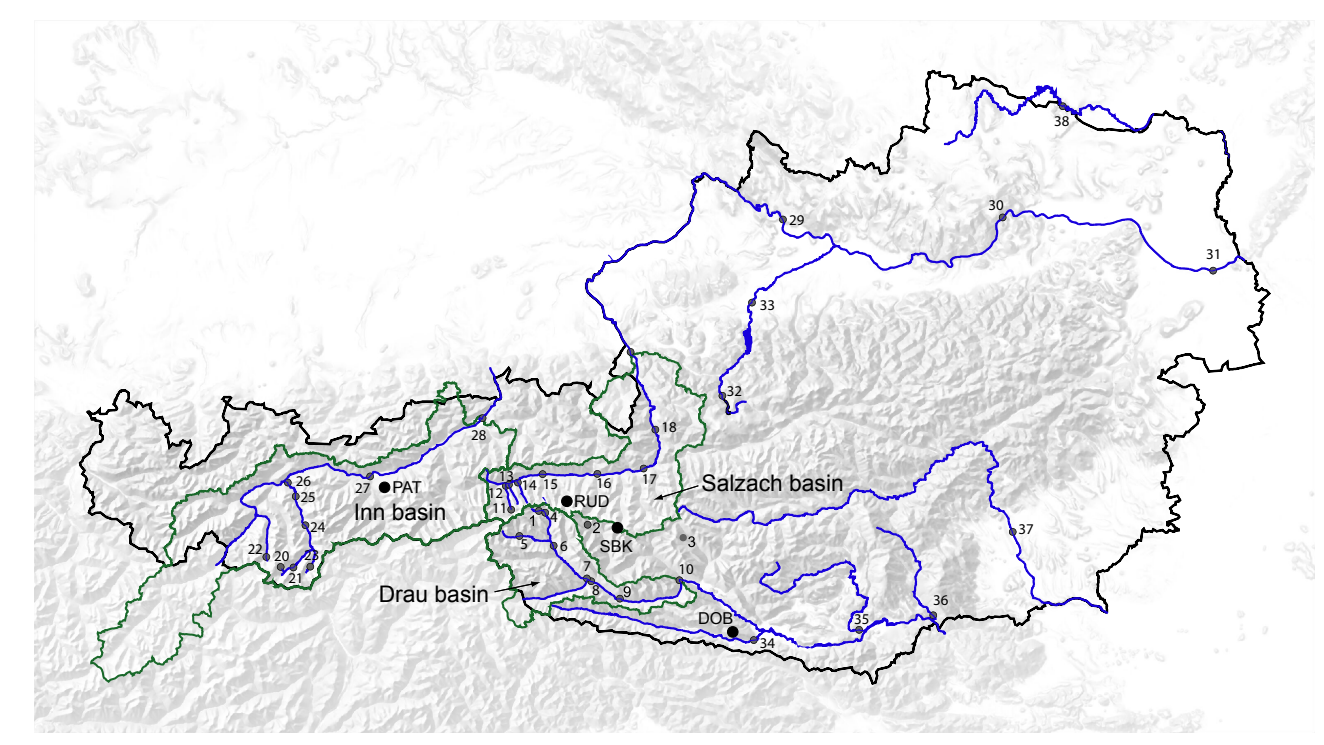

Fig. 3. Overview of investigated gauging stations (grey dots). Station numbers according to Table 2. Black dots indicate elevated meteorological stations: $\mathrm{DOB}=$ Dobratsch, $\mathrm{PAT}=$ Patscherkofel, $\mathrm{RUD}=$ Rudolfshuette, and SBK= Sonnblick (see Fig. 2). Green lines show the three main glacierized basins Inn, Salzach and Drau (data source BMLFUW, 2007).

For all 38 selected gauging stations the catchment area, the glacierized area, the degree of glacierization and the mean and minimum elevation of glaciers - if available - were derived using GIS (geographical information system). All analyses were done based on the Hydrological Atlas of Austria (BMLFUW, 2007) incorporating the maps of the latest Austrian glacier inventory, which was assessed for 1998 (Lambrecht and Kuhn, 2007). The degree of glacierization of catchment areas was calculated taking into account the actual-hydrologic conditions. Therefore the area of diverted catchments was corrected (see grey entries in Table 2) by subtracting the diverted area from the total hydrological catchment area. Vice versa the diverted area was added to the neighbouring catchment area. The same was done for the glacierized areas of water diversions. Hence the catchment area of the Inn basin was reduced by $201.6 \mathrm{~km}^{2}$ and a glacierized area of $12 \mathrm{~km}^{2}$ (Silvretta diverted into the Rhine basin in the west), the catchment area of the Isel and Drau basin was reduced by $15 \mathrm{~km}^{2}$ and a glacierized area of $1.3 \mathrm{~km}^{2}$ (Landeggbach diverted into the Salzach basin in the north) and the catchment area of the Salzach basin was increased by $85.7 \mathrm{~km}^{2}$ and a glacierized area of $24.9 \mathrm{~km}^{2}$ (diverted tributaries coming from the south from Margaritze and Landeggbach). The glacierized area of the Swiss part of the Inn basin was available from the new remote-sensing-derived Swiss glacier inventory derived for the year 2000 (Paul et al., 2002). Discharge data were online available from the Austrian Central Bureau of Hydrology (BMLFUW, 2010) back to 1951. Based on these time series of mean daily runoff from all selected gauging stations the quotient $q_{\mathrm{A} 03}$ (see Eq. 1 and Table 2) was calculated as the quotient from the mean runoff in August 2003 (MQ $\left.\mathrm{Mug}_{\mathrm{A} 3}\right)$ and the mean long-term August runoff (MQAug_long).

$q_{\mathrm{A} 03}=\frac{\mathrm{MQ}_{\text {Aug03 }}}{\mathrm{MQ}_{\text {Aug_long }}}$

To separate a period, which was dominated by the presence of melt, we decided to calculate mean runoff based on daily values from 3 to 27 August (see Fig. 2). For the last days of August 2003 extreme precipitation and floods were reported especially in the south of the Alps (Moser and Kopeinig, 2003). The mean long-term August runoff was calculated for the longest available time series for exactly the same period from 3 to 27 August. As the length of available time series was very different from about 10 to $60 \mathrm{yr}$ (see Table 2) and furthermore it was reported by Lambrecht and Kuhn (2007) that from 1969 to 1998 the glacierized area in Austria reduced from $567 \mathrm{~km}^{2}$ to $471 \mathrm{~km}^{2}$ (mean reduction of $17 \%$ ) it seemed to be obvious that results could not be compared. But if for all runoff time series the mean of the shortest 10-yearperiod is taken $q_{\mathrm{A} 03}$ values do only differ by about $\pm 10 \%$ (no significant difference in mean). Therefore we proceeded with the longest available time series and marked data points in Fig. 4 which were calculated based on time series longer than 50 years and time series between 30 and 50 yr. Furthermore the mean and minimum elevation of glaciers within the investigated catchments was calculated based on a $250 \mathrm{~m}$ digital elevation model. 
Table 2. Overview and results of investigated basins and stations (grey background indicates corrected catchtment area and glacierized areas).

\begin{tabular}{|c|c|c|c|c|c|c|c|c|c|c|c|}
\hline basin & $\mathrm{Nr}$. & HZB-ID & station name & catchment name & $\begin{array}{l}\text { length of } \\
\text { time-series } \\
\text { (years) }\end{array}$ & $\begin{array}{l}\text { catchment } \\
\text { area }\left(\mathrm{km}^{2}\right)\end{array}$ & $\begin{array}{l}\text { glacierized } \\
\text { area }\left(\mathrm{km}^{2}\right)\end{array}$ & $\begin{array}{l}\text { min. elev. } \\
\text { glaciers (m) }\end{array}$ & $\begin{array}{l}\text { mean elev. } \\
\text { glaciers }(\mathrm{m})\end{array}$ & $\begin{array}{l}\text { glacierization } \\
(\%)\end{array}$ & $\begin{array}{l}q_{\text {A03 quotient }} \\
\text { (3-27 Aug) }\end{array}$ \\
\hline \multirow{10}{*}{ 躉 } & 1 & 212068 & Innergschloess & Gschloessbach & 56 & 41 & 15 & 2320 & 2995 & 36 & 1.24 \\
\hline & 2 & & Margaritze & Moell & 7 & 71 & 24 & 2325 & 2975 & 33 & 1.54 \\
\hline & 3 & 212456 & Ochsenhütte-Hochalm & Lieser & 45 & 9 & 3 & 2770 & 3010 & 31 & 1.07 \\
\hline & 4 & 212076 & Matreier Tauernhaus & Tauernbach & 56 & 65 & 15 & 2320 & 2990 & 23 & 1.13 \\
\hline & 5 & 212043 & Hinterbichl & Isel & 56 & 107 & 16 & 2615 & 3025 & 15 & 0.95 \\
\hline & 6 & 212092 & Brühl & Isel & 56 & 502 & 48 & 2320 & 3005 & 10 & 0.90 \\
\hline & 7 & 212167 & Lienz & Isel & 56 & 1182 & 64 & 2320 & 3005 & 5 & 0.78 \\
\hline & 8 & 212316 & Lienz/Peggetz & Drau & 36 & 1854 & 64 & 2320 & 3005 & 3 & 0.82 \\
\hline & 9 & 212324 & Oberdrauburg & Drau & 56 & 2084 & 64 & 2320 & 3005 & 3 & 0.73 \\
\hline & 10 & 212357 & Sachsenburg & Drau & 56 & 2535 & 64 & 2320 & 3005 & 3 & 0.74 \\
\hline \multirow{9}{*}{ 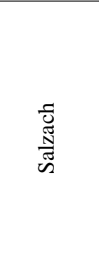 } & 11 & 203893 & Kees/Obersulzbach & Obersulzbach & 17 & 22 & 13 & 2415 & 2885 & 58 & 1.61 \\
\hline & 12 & 203034 & Sulzau & Obersulzbach & 46 & 81 & 17 & 2415 & 2910 & 21 & 1.21 \\
\hline & 13 & 203042 & Neukirchen & Untersulzbach & 36 & 41 & 6 & 2320 & 2855 & 15 & 0.89 \\
\hline & 15 & 203596 & Habach & Habach & 27 & 46 & 4 & 2565 & 2845 & 8 & 1.21 \\
\hline & 14 & 203125 & Bruck & Salzach & 56 & 1252 & 83 & 2320 & 2875 & 7 & 0.88 \\
\hline & 16 & 203075 & Mittersill & Salzach & 56 & 590 & 37 & 2320 & 2875 & 6 & 0.73 \\
\hline & 17 & 203901 & Wallnerau & Salzach & 18 & 2229 & 102 & 1955 & 2895 & 5 & 0.85 \\
\hline & 18 & 204032 & Werfen & Salzach & 12 & 3037 & 102 & 1955 & 2895 & 3 & 0.77 \\
\hline & 19 & 203398 & Salzburg & Salzach & 56 & 4506 & 104 & 1955 & 2890 & 2 & 0.60 \\
\hline \multirow{9}{*}{ 夆 } & 20 & 202689 & Vernagt & Vernagtbach & 32 & 11 & 9 & 2990 & 3200 & 76 & 2.00 \\
\hline & 21 & 201350 & Vent & Rofenache & 40 & 98 & 37 & 2755 & 3145 & 38 & 1.51 \\
\hline & 22 & 230300 & Gepatschalm & Fagge & 24 & 58 & 22 & 2225 & 3115 & 37 & 1.30 \\
\hline & 23 & 201376 & Obergurgl & Gurglerache & 41 & 63 & 21 & 2700 & 3105 & 34 & 1.19 \\
\hline & 24 & 201392 & Huben & Ötztalerache & 31 & 516 & 99 & 2630 & 3125 & 19 & 1.12 \\
\hline & 25 & 201434 & Tumpen & Ötztalerache & 56 & 785 & 114 & 2630 & 3110 & 14 & 0.98 \\
\hline & 26 & 230342 & Brunau & Ötztalerache & 16 & 870 & 114 & 2630 & 3110 & 13 & 1.09 \\
\hline & 27 & 201525 & Innsbruck & Inn & 57 & 5569 & 229 & 2225 & 3090 & 4 & 0.72 \\
\hline & 28 & 201889 & Kirchbichl & Inn & 31 & 9105 & 303 & 2225 & 3055 & 3 & 0.67 \\
\hline \multirow{5}{*}{ : } & 29 & 207035 & Aschach & Donau & 31 & 78190 & 424 & 1955 & 3010 & 1 & 0.51 \\
\hline & 30 & 207357 & Kienstock & Donau & 31 & 95970 & 413 & 1955 & 3000 & 0.4 & 0.48 \\
\hline & 31 & 207373 & Wildungsmauer & Donau & 12 & 103993 & 413 & 1955 & 3000 & 0.4 & 0.47 \\
\hline & 32 & 205252 & Steeg (Seeausfluss) & Traun & 57 & 615 & 6 & 2290 & 2545 & 1 & 0.40 \\
\hline & 33 & 207373 & Roitham & Traun & 57 & 1486 & 6 & 2290 & 2545 & 0.4 & 0.39 \\
\hline \multirow{5}{*}{ 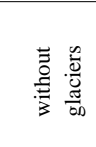 } & 34 & 212787 & Federaun & Gail & 57 & 1307 & & & & & 0.49 \\
\hline & 35 & 213041 & Gumisch & Gurk & 57 & 2554 & & & & & 0.37 \\
\hline & 36 & 213090 & Krottendorf & Lavant & 57 & 953 & & & & & 0.34 \\
\hline & 37 & 211573 & Graz m. MK & Mur & 42 & 6986 & & & & & 0.32 \\
\hline & 38 & 209171 & Hardegg & Thaya & 31 & 2382 & & & & & 0.53 \\
\hline
\end{tabular}

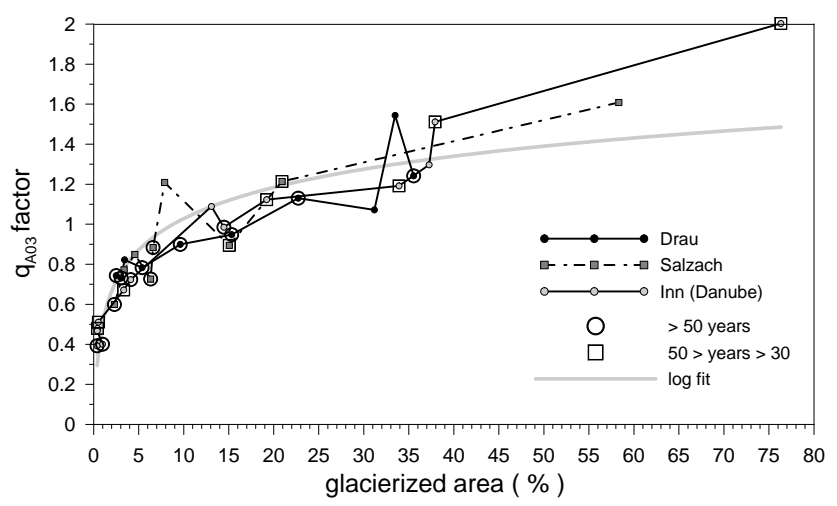

Fig. 4. Calculated August 2003 quotient $\left(q_{\mathrm{A} 03}\right)$ vs. relative glacierization of investigated catchments (see Table 2).

\section{Results and discussion}

As expected, glacier melt contributions in Fig. 1, which were gained from different studies (see Table 1), were the highest for daily observations during August 2003 and for the highest relative glacierized catchment area. Consequently, mean monthly glacier melt contributions in August 2003 were about $10 \%$ and mean annual contributions in the year 2003 were about $60 \%$ lower than the daily maximum contributions. Nevertheless, these glacier melt contributions were much higher than the (long-term) mean contributions of the Salzach and Inn basin. All fitted curves are of a logarithmic shape but especially for the 2003 monthly and daily values the glacier melt contribution strongly increases from 0 to $10 \%$ glacierization and only gently inclines for higher glacierizations from 10 to $60 \%$. This could be explained with a much higher runoff contribution of precipitation, which lowers the contributing fraction of glacier melt especially in elevated, small and highly glacierized catchments. 
There is evidence for this consideration from the investigation of Koboltschnig et al. (2007b) where it was calculated for four elevated stations in the glacierized area of Inn and Salzach river in Austria (Ötztal and Hohe Tauern region) that mean annual precipitation increased by about $60 \%$ to up to $2700 \mathrm{~mm}$ within a very short distance of less than $3 \mathrm{~km}$ horizontally and $800 \mathrm{~m}$ vertically ( $2200 \mathrm{~m}$ a.s.l. to $3000 \mathrm{~m}$ a.s.l.). Even in years of negative glacier mass balances high precipitation amounts in elevated areas can lead to a reduction of the relative glacier melt contribution. Furthermore Table 2 shows that the highest glacierization can be found for small and elevated catchments (see e.g. station nr. 20 Vernagtbach: $76 \%$ glacierized and $11 \mathrm{~km}^{2}$ total area). In Fig. 1 results of Lambrecht and Mayer (2009) were separately marked with blue rings although they have been used for the calculation of the logarithmic fit. Especially for the examples with a lower degree of glacierization data points are significantly below the logarithmic fit. This could be due to the concept of calculating the excess melt based on mass balance observations whereas the basic melt contribution of glaciers is missing.

The ten-year-mean glacier melt contributions of the Weber et al. (2009) study have been displayed separately in Fig. 1 as these values do not fit into the long-term mean values for the Inn basin. Moreover the Weber et al. (2009) glacier melt contributions of the two highly glacierized catchments are higher than the glacier melt contributions of the extreme year 2003. This could be explained by the fact that Weber et al. (2009 and 2010) provided meteorological input on a raster of $1 \times 1 \mathrm{~km}^{2}$. As the two data points, which are far away from the logarithmic curve for the Salzach resp. the Inn basin, represent the stations Vent and Huben within in the relatively dry Ötztal valley, an underestimation of precipitation caused by a too coarse grid could substantially lead to an overestimation of the glacier melt contribution. Based on the raster of $1 \times 1 \mathrm{~km}^{2}$ for the meteorological input reliable results can only be expected for catchments of more than $100 \mathrm{~km}^{2}$ in area (Weber et al., 2010). Due to the strict implemented mass conservation, no corrections of the glacier mass balances were applied in the hydrological model although a deficit of up to $250 \mathrm{~mm}$ for the winter accumulation has detected. Hence, the results for the larger basins with a lower degree of glacierization are more reliable compared to the ones of smaller catchments with a higher degree of glacierization (Weber, personal communication, 2011).

The August 2003 runoff quotients $q_{\mathrm{A} 03}$ were calculated between 0.32 , for the non-glacierized catchment area of river Mur in Graz (see entry Nr. 37 in Table 2) and 2.0 for the highly glacierized catchment area of Vernagtbach (see entry Nr. 20 in Table 2). This means that runoff in August 2003 was two-times higher than the long-term mean in the Vernagtbach catchment and only $32 \%$ of the long-term mean in the Mur catchment at gauging station Graz. For the Drau basin the runoff deficit in August 2003 could only be compensated by glacier melt from catchments with a relative glacierization of more than $15 \%$ (see entry Nr. 6 in Table 2).
For the Salzach basin an even higher degree of glacierization was necessary to compensate the runoff deficit (e.g. entry Nr. 13 in Table 2: $15 \%$ glacierized but $q_{\mathrm{A} 03}$ only 0.89 ). In that comparison the $q_{\mathrm{A} 03}$ quotientof Habach catchment $\left(q_{\mathrm{A} 03}=1.21\right)$ is exceptional as the area is only $8 \%$ glacierized. There could have been an impact of local non-observed thunderstorms. Furthermore for the Inn basin the glacierization in catchments without runoff deficit ( $q_{\mathrm{A} 03}$ close to 1) was between 13 and $14 \%$ (see entries Nr. 25 and 26 in Table 2). This difference between the three basins Drau, Salzach and Inn could be explained by different precipitation contributing to runoff during August 2003 (see Fig. 2). If the sub-catchments with the highest glacierizations (Nr. 1, 11 and 20 in Table 2) are compared it can be seen that for the Vernagtbach catchment (Nr. 19 in Table 2) the mean and the minimum elevation of glaciers is the highest. Nevertheless, the quotient $q_{\mathrm{A} 03}$ is the highest for Vernagtbach, as the hot summer of 2003 even affected this elevated site. As $q_{\mathrm{A} 03}$ quotients in non-glacierized catchments were between 0.32 and 0.53 (see entries from Nr. 34 to Nr. 38 in Table 2) and $q_{\mathrm{A} 03}$ quotients in the Donau basin were between 0.39 and 0.51 (see entries from Nr. 29 to Nr. 33 in Table 2) - hence of nearly the same size - it could be concluded that a very small degree of glacierization of about $1 \%$ was not sufficient to even partly compensate for the runoff deficit in August 2003.

In Fig. 4 runoff quotients $q_{\mathrm{A} 03}$ of glacierized catchments are displayed vs. the corresponding relative glacierization (see also Table 2). Although runoff time-series used to calculate $q_{\mathrm{A} 03}$ quotients are of different lengths the logarithmic curve fits best with an $R^{2}$ of 0.82 . Taking only the longest available runoff time-series ( $>50 \mathrm{yr}$ ) the logarithmic fitting curve is shifted down by a relative $q_{\mathrm{A} 03}$ value of about 0.2 . This means that the difference of August 2003 runoffs compared to long-term mean August runoffs is smaller than for shorter time series.

Anyhow, the result of the logarithmic correlation between $q_{\mathrm{A} 03}$ quotient and relative glacierized catchment area is a good qualitative proof for the empiric relation of the glacier melt contribution and the relative glacierized area (Fig. 1). Although there is a complex physical context describing melt processes and meteorological characteristics the $q_{\mathrm{A} 03}$ quotient-approach, based on a large number of observations, is able to give an empirical logarithmic relation, which supports the validity of the logarithmic model based on available model and calculation results from different studies (see Fig. 1).

\section{Conclusions}

For the European Alps already several studies were performed to derive the glacier melt contribution to runoff. If historical glacier changes should be considered in models then DEMs of the glacier surface describing the threedimensional volume change must be available. To investigate 
the future glacier melt contribution models are needed, which are able to continuously update the glaciers surface change. For small scale studies even the flow and movement of glaciers have to be considered. Hence, the application of a sophisticated glacio- hydrological model to determinate the glacier melt contribution makes sense, as it is able to simulate all runoff components. Even the excess-melt approach of Lambrecht and Mayer (2009) is a good and practicable approach as it is easily applicable, assuming necessary data are available. But results only consider the glacier storage change and not ice melt contribution.

Results of this study show that there is a logarithmic relationship between the glacier melt contribution and the relative glacierized area. From this statistical model a significant increase of melt contribution with glacerization of the catchment between about 0 and $10 \%$ can be derived for years with atmospheric conditions close to the mean climate. However, for the same atmospheric conditions and for relative glacierization values greater $10 \%$ the ratio of glacier melt to total discharge levels out at about $10 \%$ as the increasing absolute value of glacier melt with glacierization is levelled out by the increase of precipitation with altitude. For extreme years with respect to the mean climate, as e.g. 2003, the logarithmic model shows a maximum glacier melt contribution of about $25 \%$ for the annual mean and up to about $80 \%$ for a single month (August 2003) as well as up to $100 \%$ for single days of August 2003 in highly glacierized catchments. The consistency of results from the incorporation of several Austrian catchments with different precipitation climate and data from several studies with different approaches underlines the robustness of findings, though there is still some uncertainty from e.g. different reference periods of studies.

Further evidence of the findings was found by assessing the $q_{\mathrm{A} 03}$ quotient for several Austrian catchments, which suggested the same logarithmic regression. Furthermore our study shows that for general statements on melt contribution of glaciers on a large scale there is no need to distinguish between bare ice melt or glacier storage change. Based on the regression shown in Fig. 1 it is possible to derive firstguess values of the glacier melt contribution from a relative glacierized area. This can be done not only to calculate a mean contribution but also to estimate a maximum value of the possible contribution.

Nevertheless, the results of Huss et al. (2008) and Weber et al. (2009) have shown that the ongoing retreat of glaciers will in future lead to a shift of the runoff regime from glacial to nival, especially for small and highly glacierized catchments. So glaciers are not only contributors to runoff - the effect of compensation during the annual water cycle is of an even higher importance. Hence, the predicted change of the runoff regime seems to be the most effective impact, which the retreat of glaciers will have on water management in the European Alps. Some studies concerning the impacts of droughts in summer 2003 have shown "a shape of things to come" (Beniston, 2004) but did not take into account that in the Alps glaciers still were available to at least partly compensate for the lack of precipitation.

Acknowledgements. The Hydrographic Service of Salzburg provided time-series of the station Kees/Obersulzbach. The authors are grateful to the editor Rolf Weingartner and two anonymous reviewers who helped to improve the paper substantially with their valuable comments.

Edited by: R. Weingartner

\section{References}

Beniston, M.: The 2003 heat wave in Europe: A shape of things to come?, An analysis based on Swiss climatological data and model simulations, Geophys. Res. Lett., 31, L02202, doi:10D1029/2003GL018857, 2004.

BMLFUW: Digital Hydrological Atlas of Austria, available at: http: //www.boku.ac.at/iwhw/hao/, 2007.

BMLFUW (Central Bureau of Hydrology, Austria): eHYD - Hydrographische Messstellen (Expertenapplikation), Historical discharge data from selected gauging stations in Austria: http: //ehyd.lfrz.at/, last access 10 December 2010.

Collins, D. N.: Climatic warming, glacier recession and runoff from Alpine basins after the Little Ice Age maximum, Ann. Glaciol. 48, 119-124, 2008.

Eybl, J., Godina, R., Lalk, P., Lorenz, P., Müller, G., and Weilguni, V.: Das Trockenjahr 2003 in Österreich, Mitteilungsblatt des Hydrographischen Dienstes in Österreich, Nr. 83, 1-38, 2005

Huss, M., Farinotti, D., Bauder, A., and Funk, M.: Modelling runoff from highly glacierized alpine drainage basins in a changing climate, Hydrol. Process., 22, 3888-3902, doi:10.1002/hyp.7055, 2008.

Huss, M., Funk, M., and Ohmura, A.: Strong Alpine glacier melt in the 1940 s due to enhanced solar radiation, Geophys. Res. Lett., 36, L23501, doi:10.1029/2009GL040789, 2009.

Koboltschnig, G. R.: Mehrfachvalidierung hydrologischer Eis- und Schneeschmelzmodelle in hochalpinen, vergletscherten Einzugsgebieten. PhD study at the University of Natural Resources and Applied Life Sciences, Vienna, 164p, available at: http://iwhw. boku.ac.at/dissertationen/koboltschnig.pdf, 2007a.

Koboltschnig, G. R, Schöner, W., and Holzmann, H.: Extensive hydrological monitoring of a small, highly glacierized watershed in the Hohe Tauern region, Austrian Alps, IAHS Publ. 318, $2007 \mathrm{~b}$.

Koboltschnig, G. R., Schöner, W., Zappa, M., Kroisleitner, Ch., and Holzmann, H.: Runoff modelling of the glacierized Alpine Upper Salzach basin (Austria): multi-criteria result validation, Hydrol. Process., 22, 3950-3964, doi:10.1002/hyp.7112, 2008.

Koboltschnig, G. R., Schöner, W., Zappa, M., and Holzmann, H.: Glaciermelt of a small basin contributing to runoff under the extreme climate conditions in the summer of 2003, Hydrol. Process., 23, 1010-1018, doi:10.1002/hyp.7203, 2009.

Kuhn, M.: The Reaction of Austrian Glaciers and their Runoff to Changes in Temperature and Precipitation Levels, Österreichische Wasser- und Abfallwirtschaft, 56(1-2), 1-7, 2004.

Kuhn, M., Olefs, M., and Fischer, A.: Auswirkung von Klimaänderungen auf das Abflussverhalten von vergletscherten Einzugsgebieten im Hinblick auf Speicherkraftwerke (Global 
change and its effect on runoff behaviour of glacierised basins with regard to reservoir power stations, StartClim2007.E), a contribution to: Impacts of Climate Change on Austria: Case Studies, available at: http://www.austroclim.at/fileadmin/user upload/reports/StCl07E.pdf, 2007.

Kuhn, M., Abermann, J., Olefs, M., Fischer, A., and Lambrecht, A.: Gletscher im Klimawandel: Aktuelle Monitoringprogramme und Forschungen zur Auswirkung auf den Gebietsabfluss im Ötztal. Mitteilungsblatt des Hydrographischen Dienstes in Österreich, Nr. 86, 31-48, 2009.

Lambrecht, A. and Kuhn, M.: Glacier changes in the Austrian Alps during the last three decades, derived from the new Austrian glacier inventory, Ann. Glaciol., 46, 177-184, 2007.

Lambrecht, A. and Mayer, Ch.: Temporal variability of the non-steady contribution from glaciers to water discharge in western Austria, J. Hydrol. 376, 353-361, doi:10.1016/j.jhydrol.2009.07.045, 2009.

Moser, H. and Kopeinig, Ch.: Hochwasser am Vorderberger Wildbach, 29.08.2003, Dokumentation - hydrologische/hydraulische Analyse, available at: http://www.ktn.gv.at/19566_DE, 2003.

Oerlemans, J., Anderson, B., Hubbard, A., Huybrechts, P., Jóhannesson, T., Knap, W. H., Schmeits, M., Stroeven, A. P., van de Wal, R. S. W., and Wallinga, J.: Modelling the response of glaciers to climate warming, Clim. Dynam., 14/4, 267-274, doi:10.1007/s003820050222, 1998.

Parajka, J. and Blöschl, G.: Validation of MODIS snow cover images over Austria, Hydrol. Earth Syst. Sci., 10, 679-689, doi:10.5194/hess-10-679-2006, 2006.

Paul, F., Kääb, A., Maisch, M., Kellenberger, T. and Haeberli, W.: The new remote-sensing-derived Swiss glacier inventory. I. Methods. Ann. Glaciol., 34, 355-361, 2002.
Paul, F., Machguth, H., and Kääb, A.: On the impact of glacier albedo under conditions of extreme glacier melt: the summer of 2003 in the Alps, EARSeL eProceedings, 4(2), 139-149, 2005.

Schaefli, B., Hingray, B., Niggli, M., and Musy, A.: A conceptual glacio-hydrological model for high mountainous catchments, Hydrol. Earth Syst. Sci., 9, 95-109, doi:10.5194/hess-995-2005, 2005.

Schaefli, B., Hingray, B., and Musy, A.: Climate change and hydropower production in the Swiss Alps: quantification of potential impacts and related modelling uncertainties, Hydrol. Earth Syst. Sci., 11, 1191-1205, doi:10.5194/hess-11-11912007, 2007.

Schär, C. and Jendritzky, G.: Hot news from summer 2003, Nature, 432, 559-560, 2004.

Slupetzky, H. and Wiesenegger, J.: Glazialhydrologische Aspekte des Jahres 2003 im "Hohe Tauern Einzugsgebiet" der Salzach, Mitteilungsblatt des Hydrographischen Dienstes in Österreich, Nr. 83, 61-81, 2005.

Weber, M., Braun, L., Mauser, W., and Prasch, M.: The relevance of glacier melt for the upper Danube River discharge today and in the future, Mitteilungsblatt des Hydrographischen Dienstes in Österreich, Nr. 86, 1-29, 2009.

Weber, M., Braun, L., Mauser, W., and Prasch, M.: Contribution of rain, snow- and icemelt in the upper Danube discharge today and in the future, Geogr. Fis. Dinam. Quat., 33, 221-230, 2010.

WGMS (World Glacier Monitoring Service), Glacier Mass Balance Bulletin No. 8 (2002-2003), edited by: Haeberli, W., Noetzli, J., Zemp, M., Baumann, S., Frauenfelder, R., Hoelzle, M., Department of Geography, University of Zürich: Zürich; 100 pp., 2005.

Zappa, M. and Kan, C.: Extreme heat and runoff extremes in the Swiss Alps, Nat. Hazards Earth Syst. Sci., 7, 375-389, 2007, http://www.nat-hazards-earth-syst-sci.net/7/375/2007/. 